Макаренко С.C.

\title{
ДЕКОМПОЗИЦІЯ СТРАТЕГІЧНИХ ПРІОРИТЕТІВ РОЗВИТКУ ЛІСОГОСПОДАРСЬКИХ ПІДПРИЕМСТВ
}

\begin{abstract}
Стаття присвячена розробиі декомпозииї методичного та практичного інструментарію формування стратегії розвитку лісогосподарських підприємств малолісистого регіону на основі проведення PESTLEаналізу та кластерного аналізу. PESTLE-аналіз є концентрованою характеристикою стану речей в розрізі політичних, економічних, технологічних, правових, екологічних та сочіальних складових. В результаті кластерного аналізу лісогосподарських підприємств малолісного регіону сформувались три кластери відповідно до інтенсивності господарювання. Що створило підгрунтя для представлення базових цілей: адаптації до змін клімату лісогосподарських підприємств; зміни відношення суспільства до лісу, лісового господарства, як до сочіально важливого сектору економіки, як до суб'єкта суспільного інтересу та користі; розширеного відтворення лісових ресурсів; самоокупності та самофінансування діяльності лісогосподарських підприємств. А також проведено розукрупнювання вказаних иілей на забезпечуючі компоненти, на основі яких сформовано «дерево розвитку» лісогосподарських підприємств регіону.

Ключові слова: стратегія, лісогосподарські підприємства, РЕSTLE-аналіз, кластеризація, пріоритети розвитку
\end{abstract}

Постановка проблеми. Діяльність лісогосподарських підприємств набуває сенсу через призму економіко-суспільних інтересів: для суспільства - гармонійний та сталий розвиток; для держави - рівень соціально-економічного розвитку та поліпшення екологічного стану; для лісогосподарських підприємств - задовольнити інтереси держави і народу; для підприємців примноження доходу. Тому, враховуючи специфіку лісогосподарських підприємств необхідно «вписування» системи заходів управління лісовими ресурсами у динаміку лісу задля досягнення господарських цілей 3 найменшим порушенням лісових екосистем. Формування стратегії має стати основою, i одночасно інструментом ефективного та адаптивного розвитку для вирішення перспективних економічних завдань й досягнення соціально-економічної результативності.

Аналіз останніх досліджень i публікацій. Проблематика економіки та стратегічних пріоритетів розвитку лісового господарства та лісогосподарських підприємств досить популярна в останні роки, знаходиться у площині наукового дослідження та перебуває у просторі підвищеної уваги науковців, серед яких слід виділити: I. Дідович, А. Дейнеку, П. Диньку, О. Дребот, Р. Дубаса, А. Карпука, К. Кудряшову, І. Лицур, В. Мертенс, М. Сатто, І. Синякевич, І. Соловія, Ю. Туницю, О. Фурдичко, М. Вільямс й інших вчених.

ФМакаренко С. С. здобувач, Національний науковий центр «Інститут агарної економіки», Київ, e-mail: svitlana_stepanivna@ukr.net
Формулювання цілей статті. Змоделювати декомпозицію стратегії розвитку лісогосподарських підприємств та представити іiі у вигляді «дерева розвитку».

Опис основного матеріалу дослідження. Ліс це природне багатство, а діяльність лісових господарств набуває сенсу через призму економіко-суспільних інтересів, які в свою чергу формують пріоритети розвитку діяльності лісового господарства:

1) для суспільства важливим є гармонійний та сталий розвиток лісового господарства, а також його раціональне використання: зростання лісистості, збереження та примноження біологічного різноманіття й природнозаповідного фонду, доступність лісових благ, виконання екосферних функцій (водоохоронних, водо- та кліматорегулюючих, захисних, санітарно-гігієнічних, рекреаційних), екологічна безпека, розвиток сільських територій тощо;

2) для держави - досягнення високого рівня соціально-економічного розвитку та поліпшення екологічного стану: зростання ВВП та конкурентноздатності лісового господарства на міжнародному ринку деревини, соціальний розвиток села та сільських територій, зменшення безробіття, інтелектуальний та науковий потенціал, інноваційна та інвестиційна діяльність, моніторинг за допомогою ГІС-технологій, вирішення енергетичних питань за допомогою вирощування дерев, які мають високі показники тепловіддачі, пріоритет права користування, тощо;

3) для лісогосподарських підприємств, як об'єктів, що задовольняють інтереси держави i 
народу: безперервне та розширене відтворення ресурсів, фінансова стійкість, кадровий потенціал, ефективний догляд та охорона лісу, матеріально-технічна забезпеченість, технічний та технологічний потенціал, лісова інфраструктура, інформаційно-методичне забезпечення, вирощування порід дерев, які $\epsilon$ швидкоростучими та спроможні виживати i розвиватися в екстремальних умовах тощо;

4) підприємницькі пріоритети полягають у примноженні доходу, а саме: збільшенні обсягу деревини, що заготовляється та недеревних ресурсів лісу, зниження віку рубок, застосуванні лісових територій як баз для відпочинку, набуття сенсу державно-приватного партнерства тощо.

Лісогосподарські підприємства здійснюють господарську діяльність, як правило, в сільській місцевості, а тому стають суб'єктами, діючими елементами системи соціально-економічного розвитку сільської території у тому числі ії економічної, виробничої, екологічної та соціальної підсистем, звідси прослідковується, що лісогосподарські підприємства повинні брати участь як у безпосередній реалізації програм сільських територій, так і в процесі їх розробки. Так як, лісогосподарські підприємства $\epsilon$ суб'єктами економіко-суспільного інтересу, і тому на практиці бачать сукупність нагальних проблем, які потребують вирішення для підвищення виробничо-економічного розвитку сільських територій та регіону. А це в свою чергу стимулює соціальний розвиток регіону і несе користь суспільству країни через призму діяльності лісових господарств.

Формування ефективної стратегії лісогосподарського підприємства потребує всебічного вивчення стану середовища підприємства, що є метою стратегічного аналізу, яка конкретизується у таких його завданнях: ідентифікація, оцінка та інвентаризація стратегічного потенціалу лісу, оцінка різнобічності використання лісових ресурсів, з'ясування стратегічної позиції лісогосподарських підприємств [1, с. 105].

Багатогранність і біологічні особливості лісогосподарського підприємства ускладнюють розробку моделі процесу стратегічного управління. На думку автора формування стратегіi розвитку лісогосподарських підприємств повинно відбуватися з врахуванням специфіки самої лісової сфери та, зокрема, діяльності конкретного лісогосподарського підприємства (рис. 1).

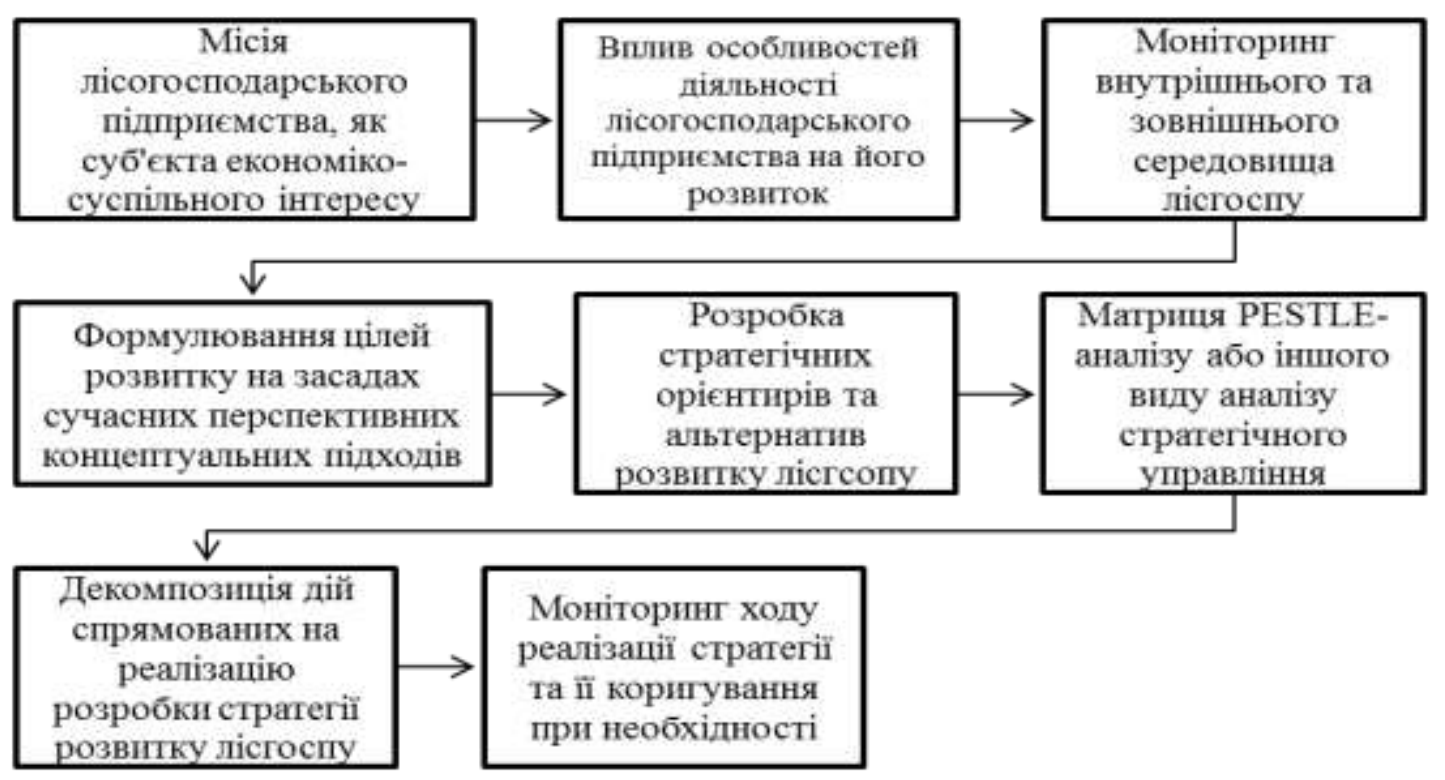

Рис. 1. Модель формування стратегії розвитку лісогосподарського підприємства*

*Розробка автора

Забезпечення правильного визначення стратегії лісгоспу й загальної політики потребує виявлення і з'ясування можливостей та загроз, які можуть виникнути для лісогосподарського підприємства в майбутньому, це $є$ задачею аналізу майбутніх можливостей і загроз. Для його проведення використано метод PESTLE-аналізу. Він застосовується для аналізу макросередовища, 100 де економіка слабо розвинута, або знаходиться в перехідному періоді. Взагалі це інструмент, призначений для виявлення наступних аспектів зовнішнього середовища, які можуть вплинути на стратегію підприємства (в тому числі лісогосподарського): політичних, економічних, соціальних, технологічних, правових та екологічних (табл. 1). 
Таблиця 1

Ключова матриця PESTLE-аналізу лісогосподарських підприємств КОУЛМГ*

\begin{tabular}{l} 
Політика \\
1. Політична нестабільність на рівні \\
країни, області (зміна влади) \\
2. Вимоги Євросоюзу щодо бартеру \\
ліквідної деревини \\
3. Недосконала система державного \\
інвестування та стимулювання галузі в \\
малолісистих управліннях \\
4. Потреба у врегулюванні питань \\
проведення $\quad$ національної \\
інвентаризації лісів через відсутність \\
якісних даних про ліси \\
5. Збільшення площі сертифікованих \\
лісів, хоча на сьогодні цей рівень \\
недостатній \\
6. Недостовірність статистичних \\
показників \\
7. Консервативні методи управління та \\
відсутність сучасного менеджменту \\
8. Відсутня державна підтримка галузі \\
та наукової діяльності \\
\hline
\end{tabular}
Соціум

1. Загострення конфліктів суспільних і приватних потреб

2. Ведення туристичної діяльності

3.Позитивним $\epsilon$ наявність лісових шкіл

4. За рахунок автоматизації виробництва відбувається зменшення робочих місць, i відтік активного населення 3 лісових регіонів через трудову міграцію

5. Низькі показники регіонального людського розвитку

6. Потреба у розвитку соціальної сфери лісгоспу, як об'єкта сільської території 7. Підвищення прозорості роботи лісового сектора

8. Низька екологічна та правова культура населення.

\section{Правові}

1.Імплементація законодавства до міжнародних нормативно-правових актів: розподіл деревини за 4 стандартами якості деревини (раніше було 3. Введення Закону про стратегічну екологічну оцінку та екологічної декларації

2. Зміни у податковій політиці: рентна плата за лісові землі та ін. і як наслідок зростання податкового навантаження на лісгоспи

3. Посилення відповідальності браконьєрство та незаконний імпорт деревини

4. Підвищення громадського контролю та уведення в дію функціонування державної лісової охорони

*на основі дослідження восьми лісогосподарських підприємств Кіровоградського обласного управління лісового і мисливського господарства

**Розробка автора
1. Мала частка участі у ВВП регіону зокрема, та країни взагалі

2. Зовнішньоекономічне законодавство: введення та дострокове скасування мораторію на експорт деревини

3. Запровадження Держлісагенством Фонду державного розвитку лі-сового господарства у зв'язку з відсутністю фінансування з 2016 р.

4. Збільшення виробничої собівартості знеособленого кубометра деревини

5. Недостатність оборотних коштів для модернізації виробництва, зношеність основних фондів

6. Високий рівень попиту на необроблені матеріали та продукцію вторинного споживання (палети, тирса, дрова, стружка та ін.)

7. Потреба у диверсифікації виробництва, збільшенні асортименту продукції, низький рівень переробки відходів

8. Недосконалий маркетинг

9. Реалізація деревини на відкритих аукціонах

10. Попит на мисливські ресурси та рекреацію

11. Наявність «тіньового сектора»
1. Потреба у залученні інноваційних технологій та інвестицій у розвиток

2. Уведення $100 \%$ електронного обліку деревини

2. Зменшення кількості лісових пожеж

3. Використання методів наближених до природи лісу

4. Потреба у підвищенні рівня біологічної стійкості деревостанів, за рахунок іх відтворення з посадкового плюсового матеріалу

5. Розширення лісової інфраструктури

6. Необхідність збільшення частки штучних насаджень та програмних лісів

7. Впроваження ГІС-технологій для моніторингу та контролю лісових ресурсів, а також інших сучасних інформаційних технологій

8. Несвоєчасне відновлення лісу на місці зрубаного та/або загиблого

9.Неефективність заходів по знешкодженню хвороб та шкідників лісу

10. Зменшення кількості диких тварин

11. Збільшення частки другорядних порід у структурі лісових насаджень та деревостанів

12. Застосування енергозберігаючих технологій.

1. Попит на екологічно «чисту» продукцію

2.3більшення обсягу поглинання вуглекислого газу та його консервація, а також розвиток ринку вуглецю

3.Потреба у стимулюванні захисного лісорозведення взагалі, та на непридатних для сільського господарства ділянках зокрема

4.Забруднення довкілля через використання хімічних препаратів боротьби iз шкідниками та хворобами, хімічних стимуляторів рості та смоловиділення

5.Влив техно- та урбано- сфери на біорізноманіття лісу, його збіднення

6.Несвоєчасна локалізація та гасіння пожеж/стихійних явищ

7.Неоптимальна вікова структура лісів, зниження їх біологічної стійкості

8. Захисне лісорозведення взагалі та на непридатних для сільського господарства землях зокрема

9. Туристичне навантаження лісової ділянки

10. Посилити водо- охоронну і -регулюючу роль лісу долі запасу, що призводить до зниження економічної продуктивності 
Ця матриця подає аналіз тенденцій, які мають істотне значення для стратегії лісогосподарського підприємства. Важливою рисою при проведенні аналізу була вимога системності стратегічного аналізу кожної з шістьох вказаних у таблиці компонент. Всі вони тісним і складним чином взаємопов'язані між собою та $\epsilon$ ключовим підгрунтям при формуванні стратегії розвитку лісогосподарських підприємств.

Світовий досвід демонструє роль кластерів в економічному розвитку i підвищенні конкурентоспроможності регіональних i національних економік.

Кластерна концепція розвитку економіки $\epsilon$ однією 3 основних сучасних концепцій підвищення конкурентоспроможності національної економіки. Під кластером розуміють сукупність підприємств i інших, задіяних в економічних процесах суб' єктів, їх інтеграцію 3 метою забезпечення досягнення конкурентної переваги тощо. Риси сучасного кластеру це - його мультифункціональність і складність структури 3 дотриманням багатовекторності. При цьому необхідно дотримуватися умов системності, яка забезпечує здатність виконання завдання господарського механізму щодо формування інноваційного русла економічного і соціального розвитку сільської території, на які, як правило, i розташовані лісогосподарські підприємства. Для отримання очікуваного ефекту потрібні постійні узгодження між трьома агентами розвитку представниками науки, лісового господарства i держави [2, с. 285-286].

При здійснені кластеризації ключовим фактором $\epsilon$ встановлення мети кластеризації вибраних об'єктів, від якої залежить подальший підбір методики, інструментів та результатів аналізу. В нашому випадку основна мета проведення кластеризації лісових господарств Кіровоградського обласного управління лісового i мисливського господарства за економічними, технічними показниками полягає в утворенні подібних груп між схожими об'єктами, виявлення зв'язку між обраними факторами та, як результат, поділ на кластери згідно ефективності діяльності.

Аналіз системи взаємозв'язків надав можливість узагальнити та сформувати групи вихідних середніх показників діяльності лісгоспів досліджуваної області, необхідних для здійснення кластерного аналізу (табл. 2).

Таблиця 2

Вихідні середні показники діяльності лісогосподарських підприємств КОУЛМГ, за 20102017 роки*

\begin{tabular}{|c|c|c|c|c|c|}
\hline $\begin{array}{l}\text { № } \\
\text { 3/ח }\end{array}$ & $\begin{array}{c}\text { Державне } \\
\text { підприємство лісове } \\
\text { господарство }\end{array}$ & $\begin{array}{c}\text { Площа (усіх видів) } \\
\text { рубок та заходів, } \\
\text { га }\end{array}$ & $\begin{array}{c}\text { Заготівля } \\
\text { деревини від усіх } \\
\text { видів рубок, } \\
\text { тис. } \text { м }^{3}\end{array}$ & $\begin{array}{c}\text { Площа лісо- } \\
\text { відтворення, га }\end{array}$ & $\begin{array}{c}\text { Обсяг продукції, } \\
\text { робіт та послуг, } \\
\text { млн грн. }\end{array}$ \\
\hline 1 & Голованівське & 1235 & 43 & 171 & 18,84 \\
\hline 2 & $\begin{array}{l}\text { Долинське у } \\
\text { «Веселі } \\
\text { Боковеньки» } \\
\end{array}$ & 152 & 6 & 220 & 3,9 \\
\hline 3 & Компаніївське & 172 & 7 & 150 & 2,66 \\
\hline 4 & Олександрівське & 776 & 47 & 194 & 25,66 \\
\hline 5 & Онікіївське & 462 & 37 & 206 & 19,01 \\
\hline 6 & Онуфріївське & 325 & 17 & 163 & 5,46 \\
\hline 7 & Світловодське & 221 & 18 & 140 & 5,69 \\
\hline 8 & Чорноліське & 614 & 44 & 163 & 31,03 \\
\hline \multicolumn{2}{|c|}{ КОУЛМГ } & 3956 & 218,56 & 1407 & 112,25 \\
\hline
\end{tabular}

*За розрахунками автора на основі офіційних статистичних даних [3, 4]

Кластерний аналіз за основними показниками діяльності лісових господарств доцільно провести за допомогою StatSoft Statistica 10.

Кластеризація з виконанням визначеної міри схожості із застосуванням графічного методу. Основною метою кластеризації за допомогою ієрархічного методу $\epsilon$ побудова дендрограми подібності лісових господарств регіону за ступенем інтенсивності діяльності (рис. 2) та подальше визначення попередньої кількості кластерів, у які їх можливо об'єднати, та відображення структури кластерів. Класифікація досліджуваних об'єктів здійснювалася 3 використанням методу Варда та метрики Евклідової відстані. Впродовж вертикальної осі наведено перелік лісових господарств регіону, які необхідно класифікувати, а впродовж горизонтальної осі відображаються відстані між об'єктами за обраними параметрами. 


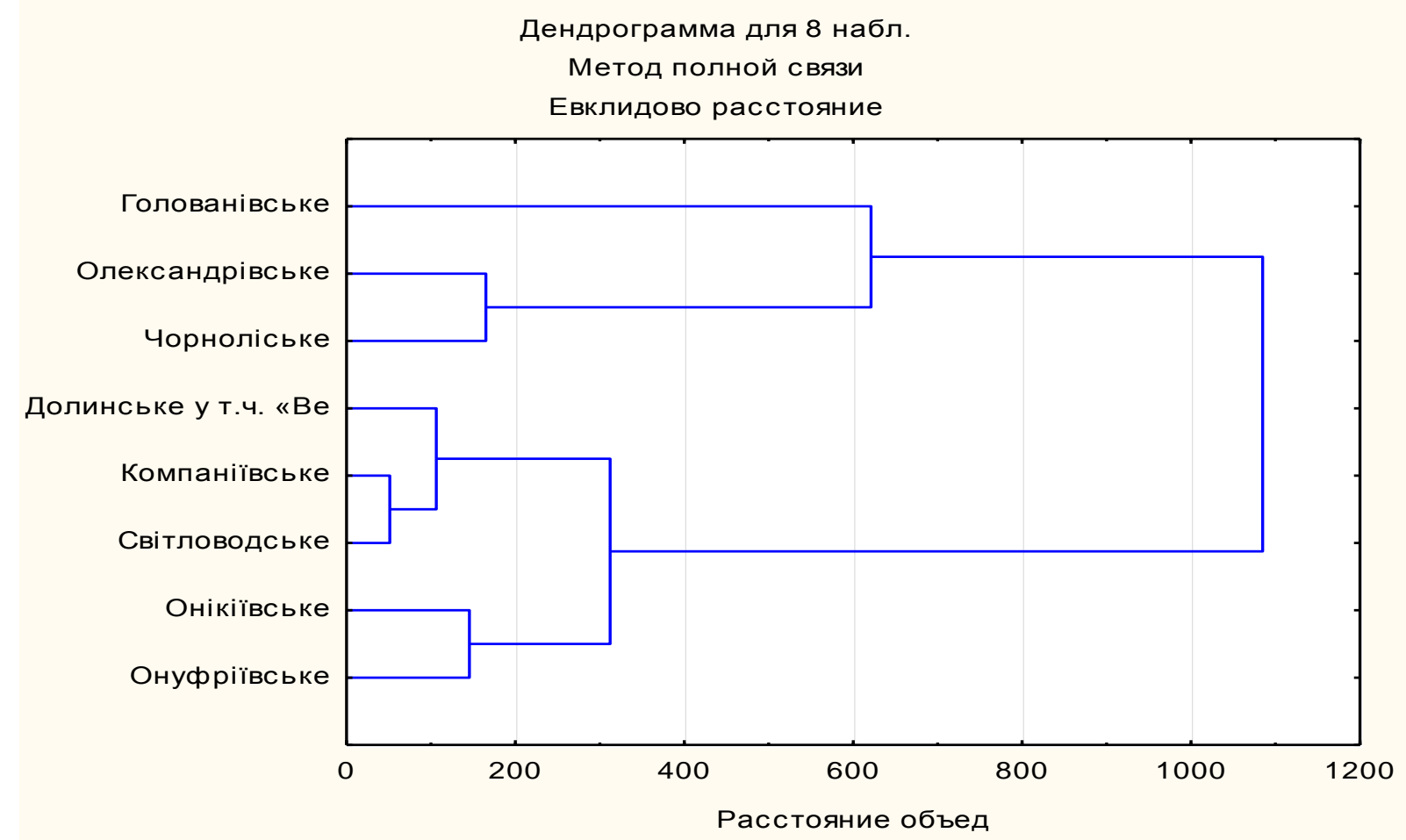

Рис. 2. Дендрограма подібності лісгоспів КОУЛМГ за ступенем інтенсивності діяльності (лістинг програми Statistica 10 версія на російській мові)*

*Розрахунки автора

Ієрархічний кластерний аналіз лісових господарств регіону за ступенем інтенсивності діяльності дає підстави стверджувати про формування трьох кластерів із відповідними лісовими господарствами:

1) Голованівське, Чорноліське - кластер I;

2) Долинське, Компаніївське, Світловодське кластер II;

3) Онікіївське, Онуфріївське - кластер III.

Ці сформовані кластери дають можливість сформувати стратегічні пріоритети розвитку лісогосподарських підприємств відповідно до спрямованості діяльності: ресурсну, захисну, природно-заповідну та ін.

Слід зазначити, що кластери сприяють активізації інноваційної діяльності лісогосподарських підприємств, що є одним із основних чинників підвищення конкурентоспроможності за рахунок накопичення в кластерах знань комерційного i виробничого характеру, а також швидкій дифузії знань в самому кластері, створення інновацій завдяки внутрішній конкуренції між виробниками кластера, прискорення впровадження інновацій в результаті співпраці між постачальниками i виробниками, придбання нововведень в рамках технологічного співробітництва в кластері. Вони також дають можливість залученню коштів місцевих бюджетів для фінансування проектів розвитку технологій та інфраструктури в рамках проектів державно-приватного партнерства, взаємного кредитування та інших форм співробітництва учасників кластера. Кластерна форма організації лісогосподарських підприємств призведе до створення особливої форми інновацій «сукупного інноваційного продукту», буде сприяти мультиплікації економічного зростання [2, с. 285-286].

Декомпозиція стратегічних пріоритетів розвитку лісогосподарських підприємств та іiі практична цінність полягає в удосконаленні механізму як прийняття ефективних управлінських рішень, господарського механізму по нарощуванню ресурсного потенціалу лісового господарства в тому числі і лісогосподарських підприємств, як необхідної передумови стійкого лісокористування в регіонах.

Розробляючи стратегію розвитку лісогосподарські підприємства повинні чітко визначити місію та цілі своєї діяльності (рис. 3).

Лісогосподарські підприємства 3 урахуванням того, що мають свої особливості об'єднані у кластери, і формування стратегії здійснюється не тільки на основі виробничої спеціалізації кластеру, а й на основі цілісного процесу: планування, користування, виробництва, збору, зберігання, продажу, відтворення. 


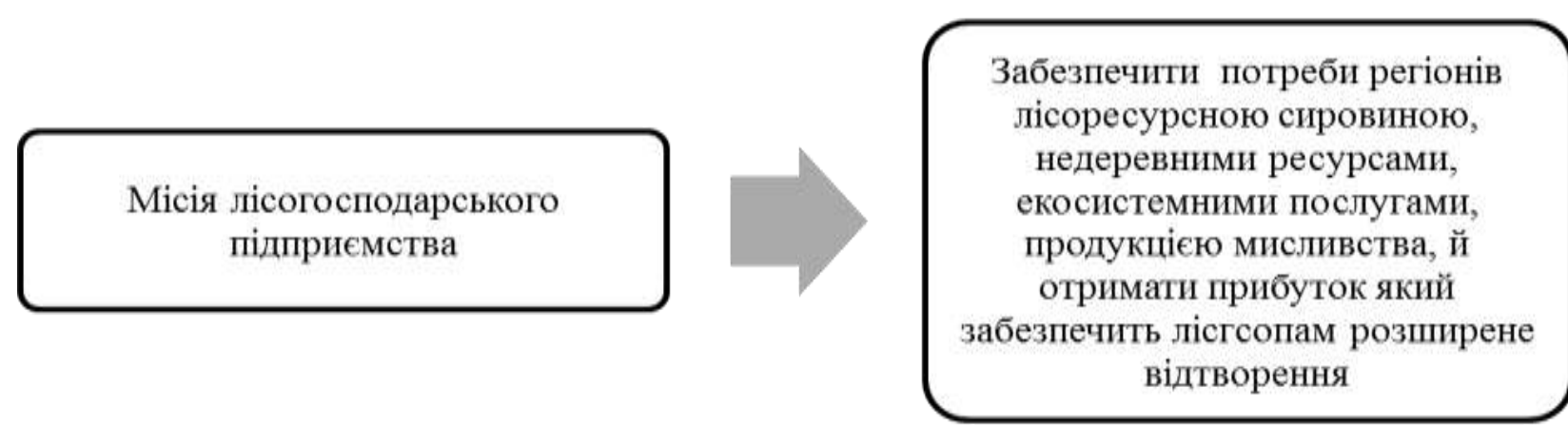

Рис. 3. Місія лісогосподарського підприємства, 2019-2024 рр.*

*Розробка автора

Лісгоспам області останні роки критичну ситуацію створюють безліч нових директивних рішень і законодавчих актів, внутрішні лісові ресурси, що зазнають впливу змін клімату, зменшення біорізноманіття, хвороб лісу, зростання агресивності зовнішнього середовища, у тому числі в сфері державного фінансування, а також динаміка ринку. У цих умовах велика роль відводиться вдалому застосуванню на практиці ідей і технологій формування стратегії розвитку. Тому стратегія розвитку лісогосподарських підприємств в 2020 р. передбачає комплексний розвиток та збільшення економічної ефективності в комплексі з урахуванням впливу змін клімату на ліс. Формування стратегії розвитку лісогосподарських підприємств Кіровоградської області буде розроблена на п’ять років, узгоджена із стратегічним планом Держлісагенства та підлягатиме чіткому контролю її виконання.
Слід відмітити, що у 2015-2019 рр. мала місце стратегія виживання у зв'язку зі політичними змінами, воєнними діями, і мала оборону позицію в умовах кризи діяльності лісогосподарських підприємств через відсутність фінансування, невиконанням державним програм та як наслідок їх закриття, устарілі методи управління та інші умови. Друга половина 2018 р. та перша половина 2019 р. характеризуються шляхом до стабілізації стану галузі та діяльності лісогосподарських підприємств. Щодо стратегії у розрізі лісогосподарських підприємств області, то тут була стратегія виживання в умовах відсутності державного фінансування. На період 2020-2024 pp. необхідно сформувати адаптивну (стабілізуючу) стратегію 3 виконанням вказаних цілей. Враховуючи вагомість кожної цілі та чинники, що забезпечують їх втілення, визначаються періоди та кластери втілення проектів (табл. 3).

\section{Компоненти формування стратегії розвитку лісгоспів КОУЛМГ 2020-2024 рр.**}

\begin{tabular}{|c|c|c|}
\hline Проекти розвитку & Забезпечюючі компоненти (умови) & Рік \\
\hline 1 & 2 & 3 \\
\hline \multicolumn{3}{|c|}{ Ціль: адаптація до змін клімату (Z1)* } \\
\hline $\begin{array}{l}\text { Технологічні, } \\
\text { екологічні }\end{array}$ & $\begin{array}{l}\text { Розвиток лісової сертифікації (Y1); } \\
\text { Збільшення лісистості (Y2); } \\
\text { Перегляд строків та видів для посадки (Y3); } \\
\text { Попередження деградації лісів (Y4); } \\
\text { Підтримка захисної і стабілізуючої функції екосистем (лісові насадження вздовж } \\
\text { річок, схилів) (Y5); } \\
\text { Дотримання принципів лісонасіннєвого районування та лісоекологічної } \\
\text { типології при проектуванні і створенні лісових культур (Y6). }\end{array}$ & 2024 \\
\hline $\begin{array}{l}\text { Організаційно- } \\
\text { управлінські }\end{array}$ & $\begin{array}{l}\text { Внесення змін до програм підготовки і перепідготовки лісівничих кадрів для } \\
\text { покращення розуміння ролі клімату і його впливу на динаміку стану лісів, } \\
\text { навчання з адаптації до змін клімату (Y7). }\end{array}$ & 2020 \\
\hline Біологічні & $\begin{array}{l}\text { Формування мішаних і складних за структурою лісостанів (Y8); } \\
\text { Мінімізація площ вирощування лісових монокультур (Y9); } \\
\text { Сприяння природному поновленню (Y10). }\end{array}$ & $\begin{array}{c}\text { до } \\
2024\end{array}$ \\
\hline \multicolumn{3}{|c|}{$\begin{array}{l}\text { Ціль: зміна відношення суспільства до лісу, лісового господарства, як до соціально важливого сектору } \\
\text { економіки, як до суб'єкта суспільного інтересу та користі }(\mathrm{Z2})^{*}\end{array}$} \\
\hline Соціальні & $\begin{array}{l}\text { Зміна ставлення до лісівничих професій, лісу як важливого елемента біосфери та } \\
\text { екосистеми (Y11); }\end{array}$ & $\begin{array}{c}\text { до } \\
2024\end{array}$ \\
\hline
\end{tabular}


Впровадження соціальних програм для працівників лісгоспів, як об'єктів сільських територій (використання паливної деревини та ін.) (Y12).

\begin{tabular}{|c|c|c|}
\hline & 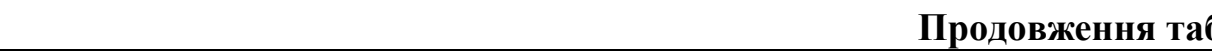 & Поц \\
\hline $\begin{array}{l}\text { Організаційно- } \\
\text { економічні }\end{array}$ & $\begin{array}{l}\text { Побудова прозорого ринку деревини, орієнтованого на невиснажливе } \\
\text { лісокористування (Y13). }\end{array}$ & $\begin{array}{c}\text { до } \\
2023\end{array}$ \\
\hline $\begin{array}{l}\text { Організаційно- } \\
\text { правові }\end{array}$ & $\begin{array}{l}\text { Реформування державної лісової охорони для розмежування функцій контролю } \\
\text { за дотриманням лісового законодавства від господарської діяльності та } \\
\text { користування лісовими ресурсами (Y14); } \\
\text { Заборона приватизації, передачі лісів у концесію (Y15). }\end{array}$ & 2021 \\
\hline Ціль & Дтворення лісових ресурсів (Z3) & \\
\hline Маркетингові & $\begin{array}{l}\text { Диверсифікація деревообробки та експорту обробленої деревини (Y16); } \\
\text { Розвиток другорядного лісокористування, надання рекреаційних послуг (Y17); } \\
\text { Чутливе реагування на потреби ринку (Y18). }\end{array}$ & 2020 \\
\hline $\begin{array}{l}\text { Економіко- } \\
\text { технологічні }\end{array}$ & $\begin{array}{l}\text { Поглиблена переробка деревини (Y19); } \\
\text { Проекти переробки лісозаготівельних відходів (Y20); } \\
\text { Обласна інвентаризація лісів у рамках національної (Y21); } \\
\text { Програмні ліси або плантаційні (Y22); } \\
\text { Відновлення лісових ресурсів протягом двох років якщо лісові насадження заги- } \\
\text { нули від пожеж, хвороб, шкідників та заліснення місць опустелювання (Y23); } \\
\text { Модернізація та оновлення виробничих фондів у найбільш економічно- } \\
\text { ефективних напрямках виробництва (Y24). }\end{array}$ & $\begin{array}{l}2020 \\
2020 \\
2024 \\
2020- \\
2022 \\
2024\end{array}$ \\
\hline Технічні & $\begin{array}{l}\text { Перехід із проведення суцільних рубок на поступово-вибіркові згідно } \\
\text { європейських стандартів (Y25); } \\
\text { Науково-обгрунтований розвиток логістики (лісові дороги тощо) (Y26); } \\
\text { Повне впровадження моніторингу на основі ГІС-технологій (Y27); } \\
\text { Врегулювання підходів до кількості та якості заповідних територій (Y28). }\end{array}$ & 2022 \\
\hline $\begin{array}{l}\text { Державно- } \\
\text { приватне } \\
\text { партнерство }\end{array}$ & $\begin{array}{l}\text { При умові відшкодування державі затрат на вирощування лісу розміром } \\
\text { орендної плати, обов'язкове відновлення насаджень протягом року після їх } \\
\text { вирубки або двох років у наслідок загибелі (Y29). }\end{array}$ & 2024 \\
\hline Ціль & та самофінансування $(\mathrm{Z4})$ & \\
\hline $\begin{array}{l}\text { Фінансово- } \\
\text { економічні }\end{array}$ & $\begin{array}{l}\text { Без залучення додаткових фінансових ресурсів: створення фонду розвитку } \\
\text { лісогосподарських підприємств, лізинг (Y30); } \\
\text { Із залученням додаткових фінансових ресурсів: фінансова допомога, позики в } \\
\text { проектах, інвестування (Y31); } \\
\text { Оптимізація податків (Y32); } \\
\text { Заходи по енергозбереженню та організації без відхідного виробництва (Y33). }\end{array}$ & $\begin{array}{c}2024 \\
2019- \\
2020\end{array}$ \\
\hline Організаційні & $\begin{array}{l}\text { Пошук антикризових резервів виробництва із залученням персоналу } 3 \\
\text { відповідним стимулюванням активних працівників (Y34). }\end{array}$ & 2020 \\
\hline
\end{tabular}

*для всіх кластерів.

**Розробка автора

Запропонована лісогосподарських можливість відповідальність, забезпечити потреби регіонів лісоресурсною сировиною, недеревними ресурсами, екосистемними послугами, продукцією мисливства, та задовольнити власні потреби у прибутковості лісогосподарських підприємств, що надасть лісгсопам додаткові кошти для розширеного відтворення. Так як ці процеси відбуваються в умовах адаптації до змін клімату, то формування стратегії розвитку відбувалося з урахуванням цих умов.

Як результат оцінки пріоритетності забезпечуючих умов представляємо «дерево розвитку», основною ідеєю якого є декомпозиція цілей та їх забезпечуючих умов. Перший рівень «дерево цілей» становитимуть проекти, які будуть визначені структурою цілей $(\mathrm{Z} 1, \mathrm{Z} 2, \mathrm{Z3}$, Z4), а другий рівень ті проекти, які визначають досягнення цілей першого рівня, тобто забезпечуючи компоненти Y (рис. 4). Формування стратегії розвитку лісогосподарського підприємства і впровадження стратегічного управління повинно поводитися послідовно і системно згідно організаційної структури та місії підприємства, має проводитися аналіз внутрішнього та зовнішнього середовищ, ураховуватися інтереси сторін, на цій основі формуються проекти розвитку та забезпечуючі умови їх досягнення, і як результат формується «дерево розвитку» лісогосподарських 
підприємств. У результаті вирішено такі завдання: розглянуті теоретичні аспекти стратегії розвитку лісгоспів, види стратегій, визначено особливості їх діяльності, запропоновано стратегію розвитку лісогосподарського підприємства на основі кластерного аналізу. Це дає можливість досягти чітко поставленої мети.

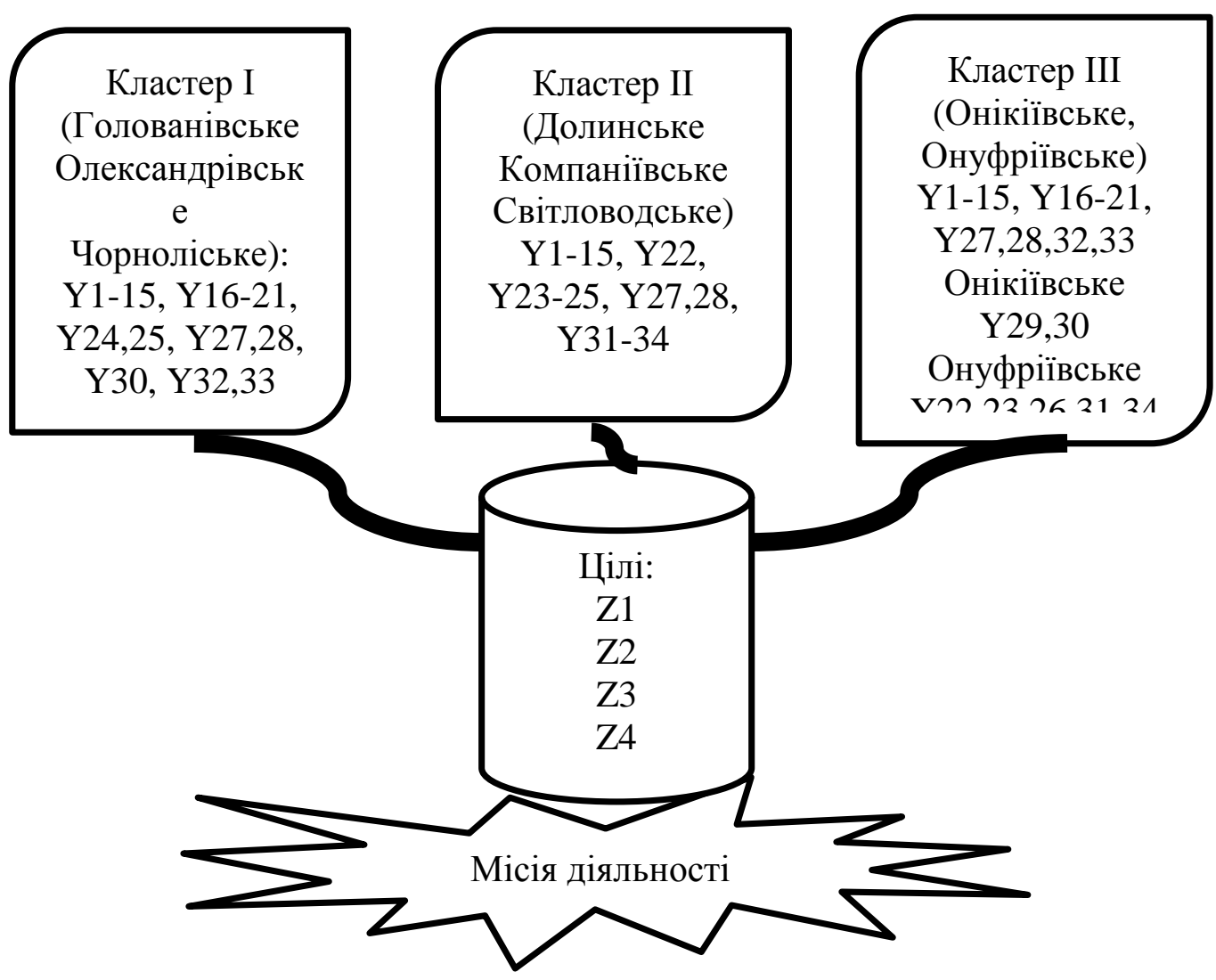

*Розробка автора

Рис. 4. «Дерево розвитку» лісогосподарських підприсмств регіону*

Висновки та перспективи подальших досліджень. Розроблено «дерево розвитку» лісогосподарських підприємств регіону, на основі декомпозиції методичного та практичного інструментарію формування стратегії розвитку лісогосподарських підприємств малолісистого регіону. Це було зроблено завдяки складанню ключової матриці PESTLE-аналізу, яка $\epsilon$ концентрованою характеристикою стану речей в розрізі політичних, економічних, технологічних, правових, екологічних та соціальних складових. Подальшим етапом дослідження був кластерний аналіз лісогосподарських підприємств малолісного регіону, в результаті якого сформувались три кластери відповідно до інтенсивності господарювання. Що створило підгрунтя для представлення базових цілей: адаптації до змін клімату лісогосподарських підприємств; зміни відношення суспільства до лісу, лісового господарства, як до соціально важливого сектору економіки, як до суб'єкта суспільного інтересу та користі; розширеного відтворення лісових ресурсів; самоокупності та самофінансування діяльності лісогосподарських підприємств. Вказані цілі було розукрупнено на забезпечуючі компоненти (умови) для кращого бачення конкретних вимірюваних задач. Подальші дослідження спрямовуються на окреслення рамок державно-приватного партнерства у діяльності лісогосподарських підприємств.

\section{ПЕРЕЛІК ВИКОРИСТАНИХ ДЖЕРЕЛ}

1. Дикань, В. Л. (2013). Стратегічне управління: навчальний посібник. Київ: Центр учбової літератури, 272. 
2. Смерічевський, С. Ф., Командровська, В. Е. (2017) Інноваційні кластери як засіб оптимізації бізнеспроцесів. Сучасні тенденції розвитку соціальної відповідальності бізнесу: матеріали Міжнародної наукової конференції (м. Лісабон, Португалія, 19 травня 2017 р.), с. 284-286.

3. Лісогосподарська діяльність за 2010-2016 роки: стат. бюл. / Держ. ком. статистики України, Головне упр. статистики у Кіровоград. обл. Кіровоград, 2011-2017.

4 Лісогосподарська діяльність за 2017 рік: стат. бюл. / Держ. ком. статистики України, Головне упр. статистики у Кіровоград. обл. Кропивницький, 2018.

\section{REFERENCES}

1. Dykan, V. L. (2013) Stratehichne upravlinnia [Strategic management]. Kiyv: Tsentr uchbovoi literytury [in Ukrainian].

2. Smerichevskyi, S. F., Komandrovska, V. E. (2017) Innovatsiini klastery yak zasib optymizatsii biznes-protsesiv [Innovative clusters as a means of optimizing business processes]. Suchasni tendentsii rozvytku sotsialnoi vidpovidalnosti biznesu: materialy Mizhnarodnoi naukovoi konferentsii (m. Lisabon, Portuhaliia, 19 travnia 2017 r.). [Modern Trends in the Development of Corporate Social Responsibility: Materials of the International Scientific Conference (Lisbon, Portugal, May 19, 2017)], 284-286. [in Ukrainian].

3. Lisogospodarska dijalnist za 2010-2016 roky [Forestry activity for 2010-2016]. (2011-2017). State Statistics Committee of Ukraine. Main Department of Statistics in the Kirovograd region. Kirovograd. [in Ukrainian].

4. Lisogospodarska dijalnist za 2018 rik [Forestry activity for 2018]. (2018). State Statistics Committee of Ukraine. Main Department of Statistics in the Kirovograd region. Kropyvnytskyi. [in Ukrainian].

Одержано 16.03.2019 